\title{
The Use of Simulation for the Design and Analysis of Thermophotovoltaic Networks
}

\author{
JE Oppenlander, JL Vell, WS Gaes, DM Siganporia, \\ LR Danielson and MW Dashiell
}

This report was prepared as an account of work sponsored by the United States Government. Neither the United States, nor the United States Department of Energy, nor any of their employees, nor any of their contractors, subcontractors, or their employees, makes any warranty, express or implied, or assumes any legal liability or responsibility for the accuracy, completeness or usefulness of any information, apparatus, product or process disclosed, or represents that its use would not infringe privately owned rights. 


\title{
The Use of Simulation for the Design and Analysis of Thermophotovoltaic Networks
}

\author{
Jane E. Oppenlander*, Jeffrey L. Vell†, William S. Gaes ${ }^{\ddagger}$, Darius M. Siganporia ${ }^{\S}$, \\ Lee R. Danielson**, and Michael W. Dashiell ${ }^{\dagger \dagger}$ \\ Lockheed Martin, P.O. Box 1072, Schenectady, NY 12301
}

\begin{abstract}
Simulation has provided valuable quantification of the fundamental behavior of thermophotovoltaic cell networks. The results of simulation studies have supported the design and fabrication of small-scale demonstration networks and are expected to guide assembly of large-scale systems. This paper describes the methodology and software simulator developed to address issues in thermophotovoltaic (TPV) networking, including failure analysis, electrical network design, and nonuniform illumination. Results from simulation studies are given illustrating their application to the design and fabrication of small-scale TPV arrays.
\end{abstract}

\section{Introduction}

Although individual thermophotovoltaic (TPV) cells have been extensively studied (Charache et al, 1999, ${ }^{1}$ Wang et al $1999^{2}$ ), the behavior of electrically connected TPV cell networks (Reiche et al, 1994 ${ }^{3}$, Pinkerton, 2000, Gow and Manning, 1999 ${ }^{4}$, Ortega et al, 2001 ${ }^{5}$, and Vaz et al, 1994 ${ }^{6}$ ) is not adequately understood to enable the construction of fault tolerant, large-scale arrays. The design of solar cell arrays is described in Rauschenbach, H.S. 1980 and Lasnier, F. 1990. However, differences exist between the operating environments and cell characteristics for TPV and solar arrays that warrant independent quantification of TPV network performance.

A viable TPV power conversion system requires a cell network that will be fault tolerant for a prescribed power rating and generator life. In particular, the electrical configuration of the network should be designed to maximize performance output of a given set of cells and to minimize the impact of operating penalties that may be incurred due to non-uniform illumination, cell variability, and cell or interconnection failure.

To address these design considerations, a relatively large number of factors must be investigated for a variety of network sizes and configurations. Simulation (Banks, J. 1984') provides an economical means for conducting a wide variety of engineering studies without constructing and testing physical TPV devices. This technique has been employed to evaluate the effect of design factors on TPV network performance using a software simulator that was developed to model the electrical behavior of TPV cells and networks.

This paper presents the results of simulation studies conducted to support the design and fabrication of two small-scale TPV arrays. In particular, the effect of cell mismatch on array performance is investigated. These results guided the electrical design and cell selection and placement for TPV arrays. The two TPV arrays considered here are an eight-cell network and a 192-cell network, representing two and 50 Watts, respectively, at a radiator temperature of $1750^{\circ} \mathrm{F}$ and cell temperature of $75^{\circ} \mathrm{F}$.

\footnotetext{
${ }^{*}$ Scientist, Advanced Software Technology Applications, Mail Stop 119, PO Box 1072, Schenectady, NY 12301

${ }^{\dagger}$ Senior Engineer, Advanced Software Technology Applications, Mail Stop 119, PO Box 1072, Schenectady, NY 12301

* Senior Software Engineer, Advanced Software Technology Applications, Mail Stop 119, PO Box 1072, Schenectady, NY 12301

${ }^{\S}$ Software Engineer, Advanced Software Technology Applications, Mail Stop 119, PO Box 1072, Schenectady, NY 12301

${ }^{* *}$ Senior Scientist, Energy Conversion Technology, Mail Stop 103, PO Box 1072, Schenectady, NY 12301

${ }^{\dagger}$ Senior Scientist, Energy Conversion Technology, Mail Stop 103, PO Box 1072, Schenectady, NY 12301
} 


\section{Methodology}

The efficiency of simulation techniques becomes especially manifest when evaluating the many factors that influence TPV network performance. Such an approach is particularly useful when hardware is limited. Additionally, conducting sensitivity studies prior to hardware assembly has yielded valuable insights into the selection and placement of cells. Further, the results of the studies predict the actual performance of the network. The combination of modeling and hardware testing is considered advantageous as it provides a comparison of empirical and theoretical results.

The TPV network design process, as shown in Figure 1, consists of

- choosing the network size, series/parallel connectivity, and interconnection resistances;

- selecting cells from the inventory and placing them into network locations;

- conducting an electrical analysis to measure network performance.

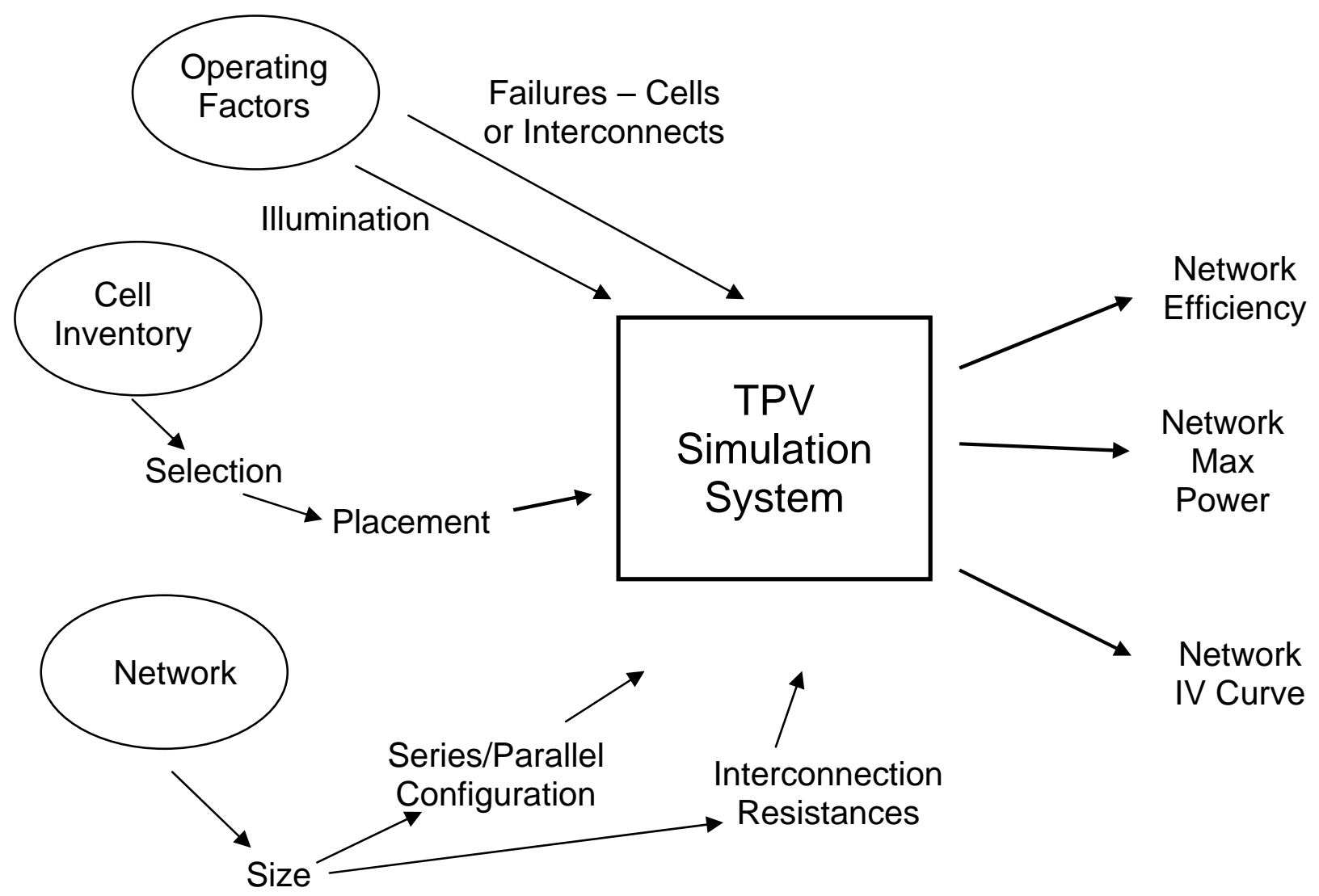

Figure 1. TPV Network Design Process

Cell selection and placement, network size, and series/parallel configuration are explicitly chosen when designing a TPV network. These inputs should be selected to mitigate the effects of non-uniform illumination and cell or interconnect failure. The TPV Simulation System allows networks to be designed and evaluated under a variety of illumination and failure conditions.

The simulation system provides a fully integrated, simulate-analyze-evaluate suite of software. The major components of the simulation system are

- cell simulator to generate electrical characteristics of cells;

- network assembly tool for specifying network characteristics and selecting and placing cells;

- electrical circuit analysis software;

- relational database for storing cell and network parameters.

Each of these software components and their associated modeling assumptions are further described below. 


\section{A. Cell Simulator}

In the simulation system, the current (I) and voltage (V) characteristics of individual cells are modeled using a modified ideal diode equation (Sze, $1969^{7}$, Danielson et al, $1999^{8}$ ):

$$
I=I_{S}\left[e^{\frac{q\left(V-I R_{s}\right)}{n k T}}-1-e^{\frac{-q\left(V-I R_{s}+V_{b r}\right)}{b k T}}\right]-I_{L}+\frac{V-I R_{s}}{R_{S H}},
$$

where, $I_{s}$ is the saturation or dark current, $I_{L}$ is the light generated current, $n$ is the ideality factor, $k$ is Boltzmann's constant, $T$ is the cell temperature, Rs is the series resistance, $R_{S H}$ is the shunt resistance, $V_{b r}$ is the breakdown voltage and $\mathrm{b}$ is the breakdown parameter.

Through a graphical user interface (GUI), each of the individual ideal diode parameters may be specified either deterministically or stochastically; in addition, a variety of statistical distributions are available. The GUI also allows the user to specify the number of cells to be simulated and additional cell properties such as active area and number of junctions. The simulated cell properties, along with appropriate identifying information, are recorded in the database.

\section{B. Network Assembly Tool}

Electrical network performance is one component of a direct energy conversion system. For the purposes of the studies described here, network performance, measured by network efficiency, $\eta_{\text {network}}$, is considered. Network efficiency is defined as,

$$
\eta_{\text {network }}=\frac{\text { Maximum Power of Network }}{\sum \text { Maximum Power of Individual Diodes }}
$$

where maximum power is the maximum electrical power point on a current-voltage curve. Network efficiency describes the (DC - nontransient) power losses incurred through a collection of interconnected cells. The network power losses can be split into two groups, those independent or those dependent on the cell characteristics. Power losses independent of the cells may be due to interconnect $I^{2} R$ losses or failed interconnections. Cell dependent power losses are due to electrical property mismatches between cells (e.g., cell failure, non-uniform illumination) which lead to electrical imbalances. These losses occur for mismatched cells (current or voltage) in either parallel or series interconnected arrays. This is due to the fact that series connected strings have a constant current and parallel connected strings have a constant voltage (Lasnier, F. $1990^{9}$, Rauschenbach, H.S. $1980^{10}$ ). For the simulation studies described here, uniform illumination is assumed over the entire array.

The network assembly software component allows the user to select

- network size and configuration;

- cells from the database to be used in the assembly;

- cell placement method.

The network assembly tool links to the database, allowing the user to select cells for evaluation in a network. The user may place cells in network locations manually through the GUI or select from a number of automatic placement options, including heuristic, random or systematic.

\section{Electrical Circuit Analysis Software}

The electrical circuit analysis software, Saber ${ }^{\circledR}$ (Synopsys, Inc.), is used to

- $\quad$ specify network size and configuration parameters;

- perform DC analysis of the network.

Network size and configuration are specified through a graphical user interface. For the results presented here, the following network interconnection characteristics were chosen:

- $\quad$ series resistance $\left(\mathrm{R}_{1}\right)$ between cells of $0.9 \mathrm{~m} \Omega$;

- $\quad$ shunt resistance $\left(\mathrm{R}_{2}\right)$ between cells of $0.1 \mathrm{~m} \Omega$.

The series resistance between cells of $0.9 \mathrm{~m} \Omega$ was chosen as the best estimate of the interconnection resistance based on measured values during module fabrication where series resistance was observed in the range of 0.44 to $1.20 \mathrm{~m} \Omega$. The shunt resistance between cells of $0.1 \mathrm{~m} \Omega$ was selected based on calculation of the resistance of the 
solder joining parallel cells. The output of the DC analysis includes the network I-V curve and key electrical measures such as short-circuit current, open circuit voltage, and maximum power. Output files are produced to allow further analysis of simulation results.

\section{Relational Database}

The database contains the properties of both "virtual" cells created by the simulation system and measured characteristics of the cells in physical inventory. Manufacturing, module fabrication, and testing information is also contained in the database. The relational design (Ramakrishnan and Gehrke, 2000 ${ }^{11}$ ) allows the database to be easily expanded to accommodate new information that must be captured as the TPV technology is developed.

\section{Results}

The use of simulation techniques to support the fabrication of two TPV demonstration arrays of successively larger size is described below. Initially, sensitivity studies were conducted to quantify the relationship between network efficiency and cell short circuit current mismatch in series connected cells. Current mismatch between series connected cells is known to limit array performance (Rauschenbach, H.S. $1980^{10}$ ). The results of the simulation studies were applied to the cell selection and placement for an eight and a 192 cell TPV array. The simulation system was used to predict the electrical performance of these two arrays. Finally, comparisons of the modeled and as-built results are given.

\section{A. Eight-Cell Array Fabrication}

The primary goals in constructing the eight-cell array were to demonstrate that electrically connecting high performing cells would result in highly efficient networks and to evaluate fabrication techniques. Figure 2 shows the electrical configurations, including shunt and series resistances for the eight-cell array.

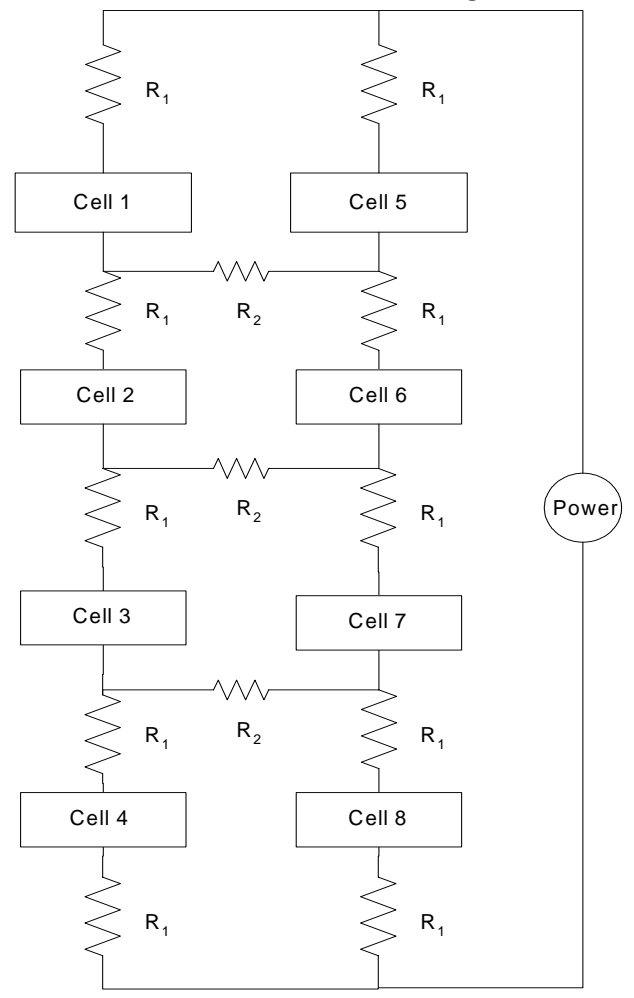

Figure 2. Electrical Connections for Eight-Cell TPV Array

For this application, simulation was used to:

- develop guidelines for cell matching and placement,

- chose cells from the available inventory and recommend their placement in the array,

- compare the simulated performance of the eight-cell array to the as-built array, and

- ascertain if selective assembly contributed to array performance. 


\section{Effect of Cell Mismatch in Series Connected Strings}

Current matching between cells is a factor contributing to a high performing array of series-connected devices. In the construction of small-scale TPV networks, cell selection and placement was investigated prior to physical assembly and test. A simulation study was performed to quantify the effects of cell mismatch on network efficiency for series-connected strings of cells. Cell characteristics were simulated based on measured electrical properties of $0.52 \mathrm{eV}$ InGaAsSb TPV diodes (Danielson et al, $1999^{8}$ ). Probability distributions were fit to the measured data in order to simulate representative cell characteristics. In this study, cell electrical characteristics were simulated based on Equation (1) and the values given in Table 1. Simulated values were truncated at the appropriate physical bound for each parameter, e.g., no negative breakdown voltages are generated.

\begin{tabular}{|l|l|l|}
\hline Cell Parameter & Units & Distribution $^{*}$ \\
\hline Saturation Current $\left(\mathrm{I}_{\mathrm{s}}\right)$ & $\mathrm{A}$ & Triangular $\left(4.31 \times 10^{-6}, 1.29 \times 10^{-5}, 2.16 \times 10^{-5}\right)$ \\
\hline Series Resistance $\left(\mathrm{R}_{\mathrm{s}}\right)$ & $\mathrm{m} \Omega$ & $\operatorname{Normal}(6.0,3.0)$ \\
\hline Ideality Factor $(\mathrm{n})$ & - & $\operatorname{Normal}(1.1,0.05)$ \\
\hline Shunt Resistance $\left(\mathrm{R}_{\mathrm{SH}}\right)$ & $\Omega$ & $\operatorname{Normal}(7.0,3.0)$ \\
\hline Light Generated Current $\left(\mathrm{I}_{\mathrm{L}}\right)$ & $\mathrm{A}$ & $\operatorname{Normal}(1.03,0.09)$ \\
\hline Breakdown Voltage $\left(\mathrm{V}_{\mathrm{b}}\right)$ & $\mathrm{V}$ & $\operatorname{Normal}(0.5,0.2)$ \\
\hline Breakdown Parameter $(\mathrm{b})$ & - & Normal(4.0,1.0) \\
\hline & $\begin{array}{l}\text { Normal(mean, standard deviation) } \\
\text { Triangular(minimum,mode,maximum) }\end{array}$ \\
\hline
\end{tabular}

Table 1. Cell Characteristics

Five hundred networks of four series-connected cells each were simulated and their electrical performance recorded. In this simulation, the simulated cells were randomly selected for placement in a string. A DC analysis was performed for each network; cell mismatch was measured as the maximum pairwise difference in the short circuit currents (Isc) of the individual cells in the network.

Figure 3 shows the results for 500 simulated four-cell series-connected networks. Network efficiency decreases and becomes more variable as cell current mismatch increases.

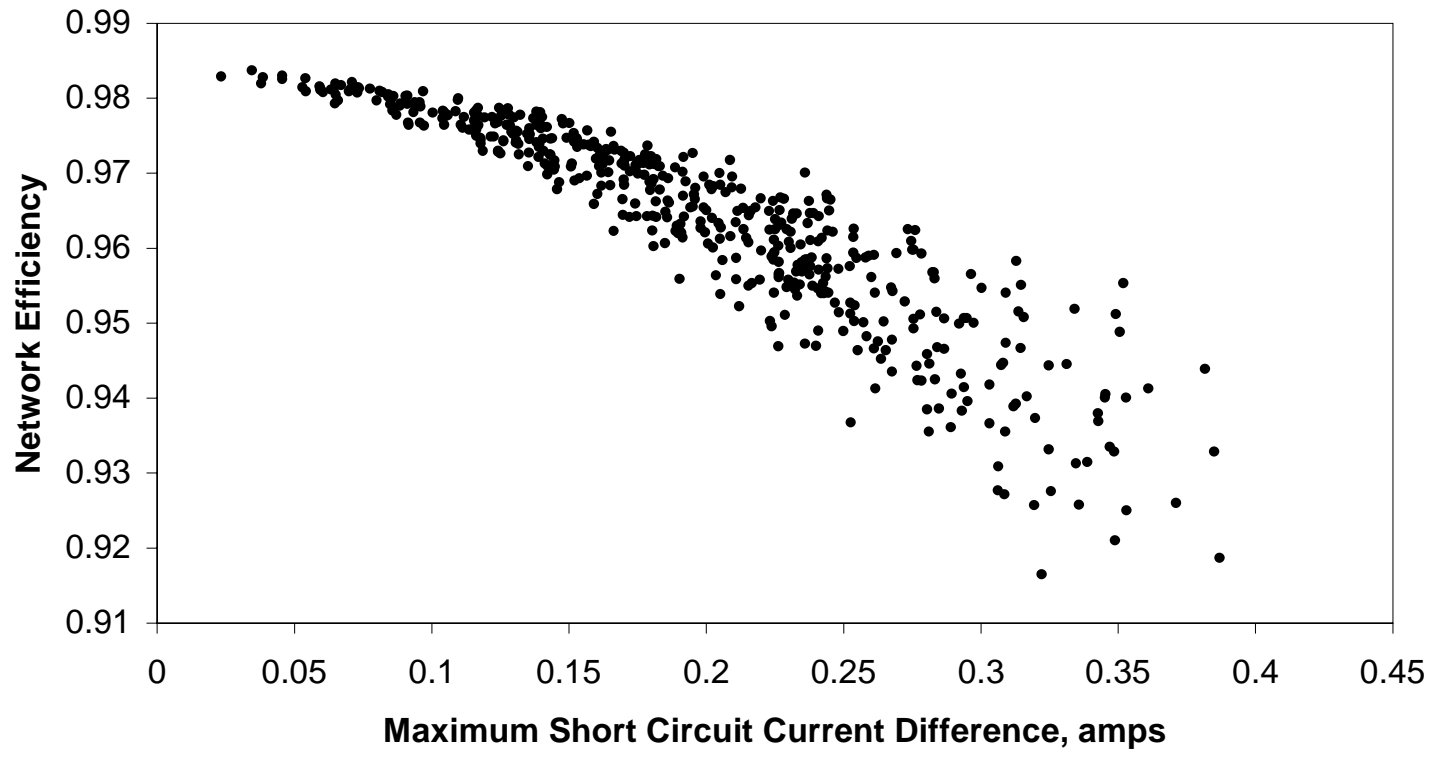

Figure 3. Network Efficiency vs. Current Mismatch for Simulated 4 Series-Connected Cell Networks

The quantification of network efficiency and cell mismatch provides a useful means to develop cell matching guidelines for network assembly. These results, coupled with practical constraints in the fabrication process, 
suggested a threshold of 0.05 amps in short circuit current mismatch for the assembly of this eight-cell network with nominal cell short circuit current of one amp. This provided a reasonable trade off between cell selection and network losses. In other circumstances, a different threshold may be appropriate.

2. Cell Selection and Placement for the Eight-Cell TPV Array

The TPV simulation system was used to select cells for the eight-cell array by evaluating the performance of numerous arrangements of cells prior to physical assembly. Using simulation allows "virtual array assembly" to identify optimal cell configurations for network fabrication.

Forty-seven actual cells from the available inventory were identified as candidates for the eight-cell array. These candidates had high levels of electrical performance and were within the dimensional tolerances required by the assembly technique. From this group, eight cells were to be chosen for fabrication into an array.

A maximum pairwise $\mathrm{I}_{\mathrm{sc}}$ difference of $0.05 \mathrm{amps}$ between series connected cells was applied as the primary cell matching criterion based on the results of the simulation study described above. The eight cells selected from the inventory had short circuit currents within 0.05 amps. A secondary matching criterion was applied which balances voltage across the parallel connections between the two strings. The application of these two matching criteria resulted in the selection of the final group of eight cells.

3. Comparison of Model and As-built Results

Figure 4 shows the power producing portion of the I-V curves for the simulation and as-built test results. Table 2 illustrates the close agreement obtained between the modeled and as-built results at key electrical points. These results provide confidence that the TPV cell networks are performing as expected compared to modeled results. This suggests that the simulation methodology can be used to investigate the fundamental behavior of TPV networks and reduce the amount of hardware testing required and its associated costs. This will be particularly beneficial as largescale TPV systems are designed.

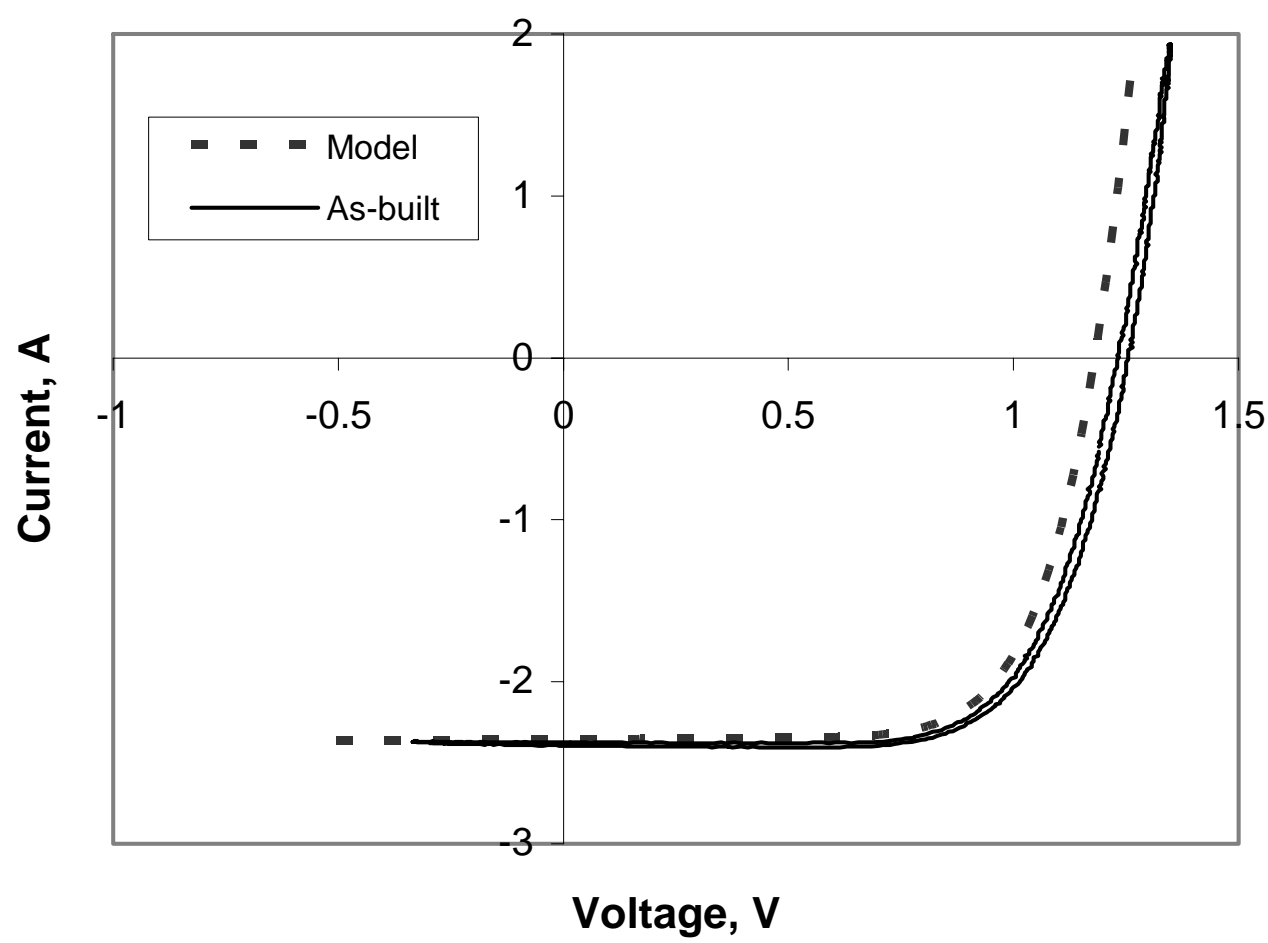

Figure 4. Comparison of simulation and test results for eight cell array 


\begin{tabular}{|c|c|c|c|c|}
\hline & $\begin{array}{c}\text { Open Circuit } \\
\text { Voltage (Volts) }\end{array}$ & $\begin{array}{c}\text { Short Circuit } \\
\text { Current (Amps) }\end{array}$ & $\begin{array}{c}\text { Fill Factor } \\
\text { (\%) }\end{array}$ & $\begin{array}{c}\text { Maximum } \\
\text { Power (Watts) }\end{array}$ \\
\hline Simulation & 1.20 & 2.31 & 70.1 & 1.95 \\
\hline As-built & 1.24 & 2.38 & 69.9 & 2.07 \\
\hline
\end{tabular}

Table II. Summary of simulated and laboratory results for eight cell array

\section{Assessment of Effectiveness of Selective Assembly}

Following the hardware test, a simulation study was conducted to assess the impact of the cell matching criteria on network efficiency. In this study, 200 simulated modules were evaluated by randomly selecting and placing eight actual cells from the original pool of 47 candidate cells. Figure 5 shows the distribution of network efficiencies obtained. The observed network efficiencies showed a 3\% range. The as-built configuration, which used cell matching criteria, ranked at the $95^{\text {th }}$ percentile of the distribution. This study will be used to improve the cell matching heuristics by evaluating the electrical characteristics of the configurations in the nine networks whose network efficiencies exceeded that of the as-built configuration. In addition, the configurations of the networks with lowest efficiencies will be evaluated to better understand arrangements that should be avoided.

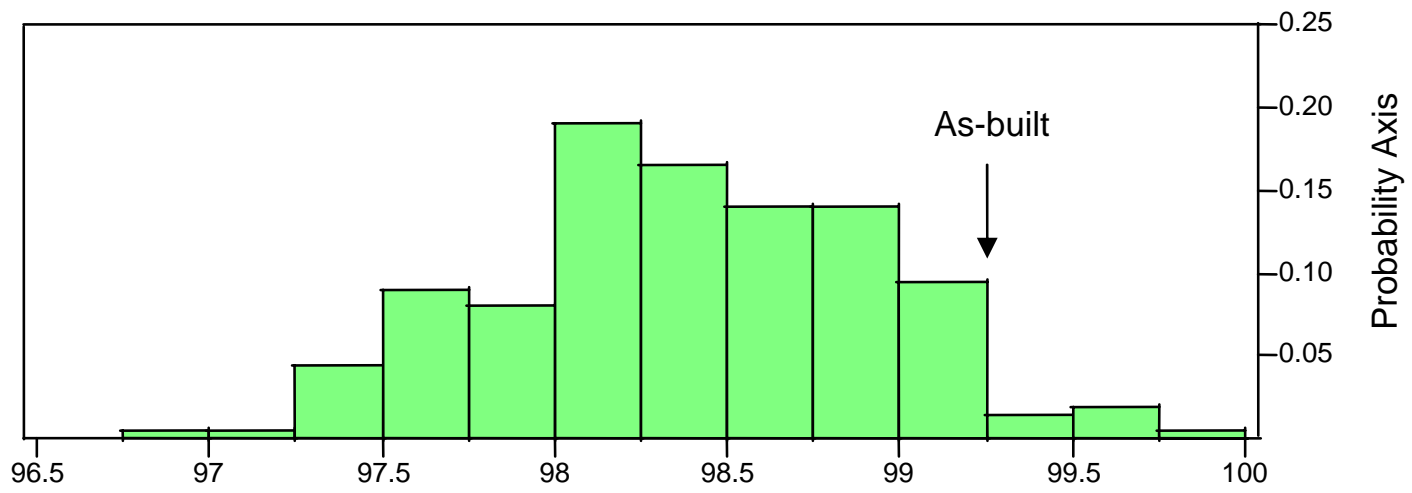

Network Efficiency, \%

Figure 5 - Distribution of Network Efficiency for 200 Networks with Randomly Selected Cells

\section{B. 192-Cell Array Fabrication}

The performance goals for this test were to achieve power output of approximately 100 watts with 12 volts using two arrays of 192 cells each. In addition, fabrication techniques were to be evaluated in a larger array than had previously been constructed (eight cell array). This section describes the fabrication of a single 192-cell array. This array consisted of four parallel-connected strings of 48 series-connected cells. Figure 6 shows the electrical configurations, including interconnection resistances for the 192-cell array. Note that the electrical configuration for the 192-cell array differs from the eight-cell array in that there are interconnections only at the top and bottom of the strings. 


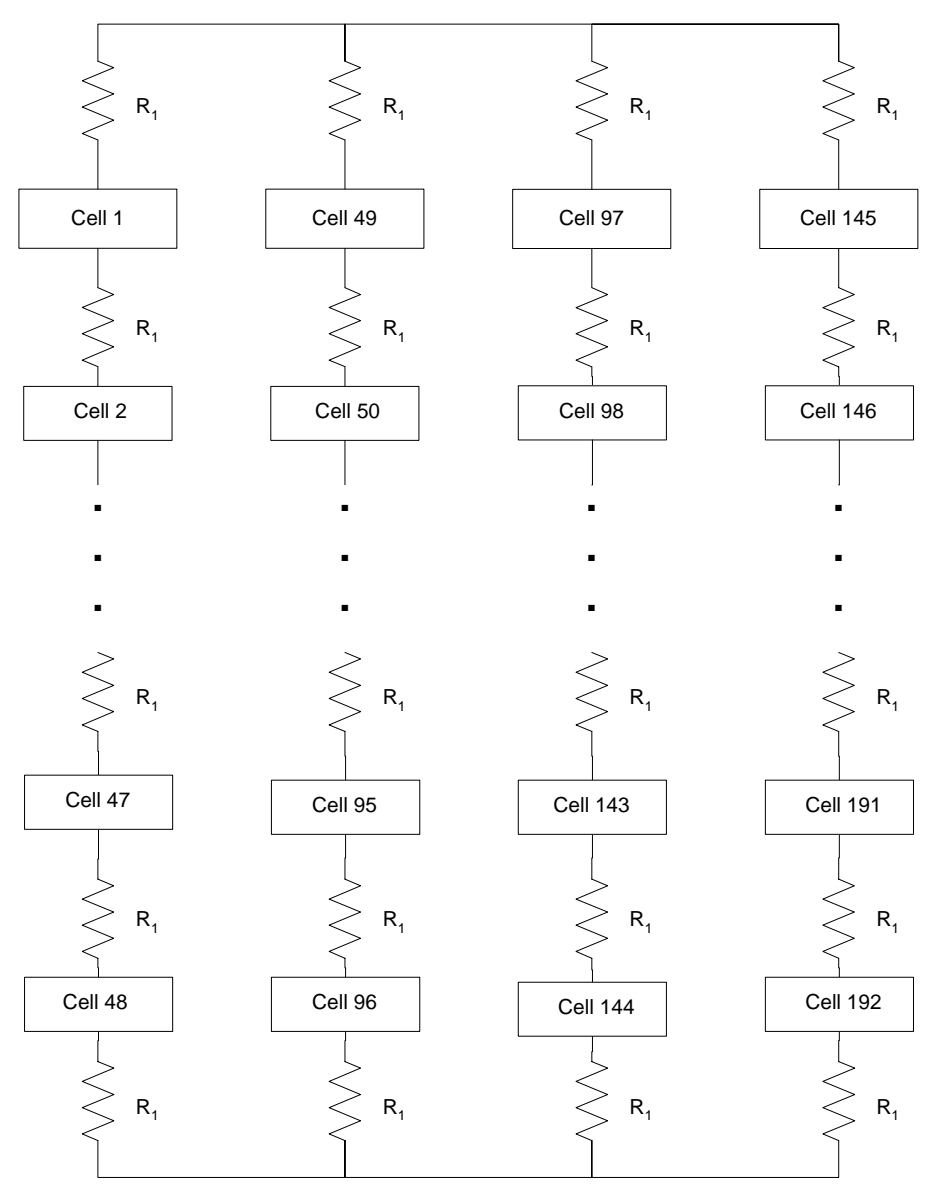

Figure 6. Electrical Connections for 192-Cell Network

This array was fabricated in the following manner. Sub-strings of eight series-connected cells were assembled. Then six sub-strings were joined to form the full string. The four strings of 48 cells were placed in the array to optimize performance for known radiator variations. For this application, simulation was used to develop guidelines for cell matching, choose cells from the available inventory and recommend their placement in the array, and compare the simulated and as-built performance.

\section{Cell Selection and Placement for the 192-Cell TPV Array}

In this application, the process was complicated by frequently changing cell inventory. Cells needed to complete the array were being manufactured and delivered, simultaneously with the fabrication of sub-strings and strings. This made it impossible to optimize the cell selection of the entire array. The cell selection process applied a just-intime philosophy. When fabricators were ready to build a 48-cell string, the current inventory was evaluated and a recommendation for the highest performing 48 well-matched cells was given. In addition, a small number of compatible "spare" cells were identified in case of damage during assembly of the string. This process was repeated for each of the four strings.

The cells were categorized by short circuit current using the threshold of a maximum difference of 0.05 amps between series-connected cells based on the results of the simulation study described above. "Bins" of cells with similar ( $\mathrm{I}_{\mathrm{sc}}$ within $0.05 \mathrm{amps}$ ) currents were created and as new cells arrived they were assigned to the appropriate bin. An additional complication arose in the course of the fabrication when it was discovered that cells were not of uniform dimension. Therefore, an additional constraint was added to the cell selection process that required cells within a bin to also be within a specified dimensional tolerance $(0.1 \mathrm{~mm})$. The TPV Simulation System and cell selection process were sufficiently flexible to accommodate this additional fabrication constraint.

2. Comparison of Model and As-built Results

Throughout the fabrication of the 192-cell array, eight-cell substrings and 48-cell strings were modeled and compared to preliminary test results. This was valuable for diagnosing potential problems as the assembly process 
progressed. Comparison of the modeled and as-built results provided insights suggesting additional non-destructive tests or corrective actions that should be performed to improve the performance of the strings and sub-strings prior to joining the strings to form the final array.

Table 3 illustrates the close agreement obtained between the modeled and as-built results at key electrical points in the power producing region. Figure 7 shows the power producing portion of the I-V curves for the simulated and as-built test results of the 192-cell array. The model shows horizontal behavior in the negative and low voltage region while the as-built results exhibit a negative slope. These differences are believed to be due to the effects of non-uniform illumination, low cell shunt resistances, or other cell degradation incurred during array construction. These results suggest the need for further investigation to determine the causes of the discrepancies. This will result in either a model that more realistically represents TPV arrays or improvements to the TPV fabrication methods.

\begin{tabular}{|c|c|c|c|c|}
\hline & $\begin{array}{c}\text { Open Circuit } \\
\text { Voltage (Volts) }\end{array}$ & $\begin{array}{c}\text { Short Circuit } \\
\text { Current (Amps) }\end{array}$ & $\begin{array}{c}\text { Fill Factor } \\
\text { (\%) }\end{array}$ & $\begin{array}{c}\text { Maximum } \\
\text { Power (Watts) }\end{array}$ \\
\hline Simulation & 13.24 & 3.96 & 68.37 & 35.83 \\
\hline As-built & 13.21 & 4.04 & 66.34 & 35.19 \\
\hline
\end{tabular}

Table 3. Summary of simulated and as-built results for 192-cell array

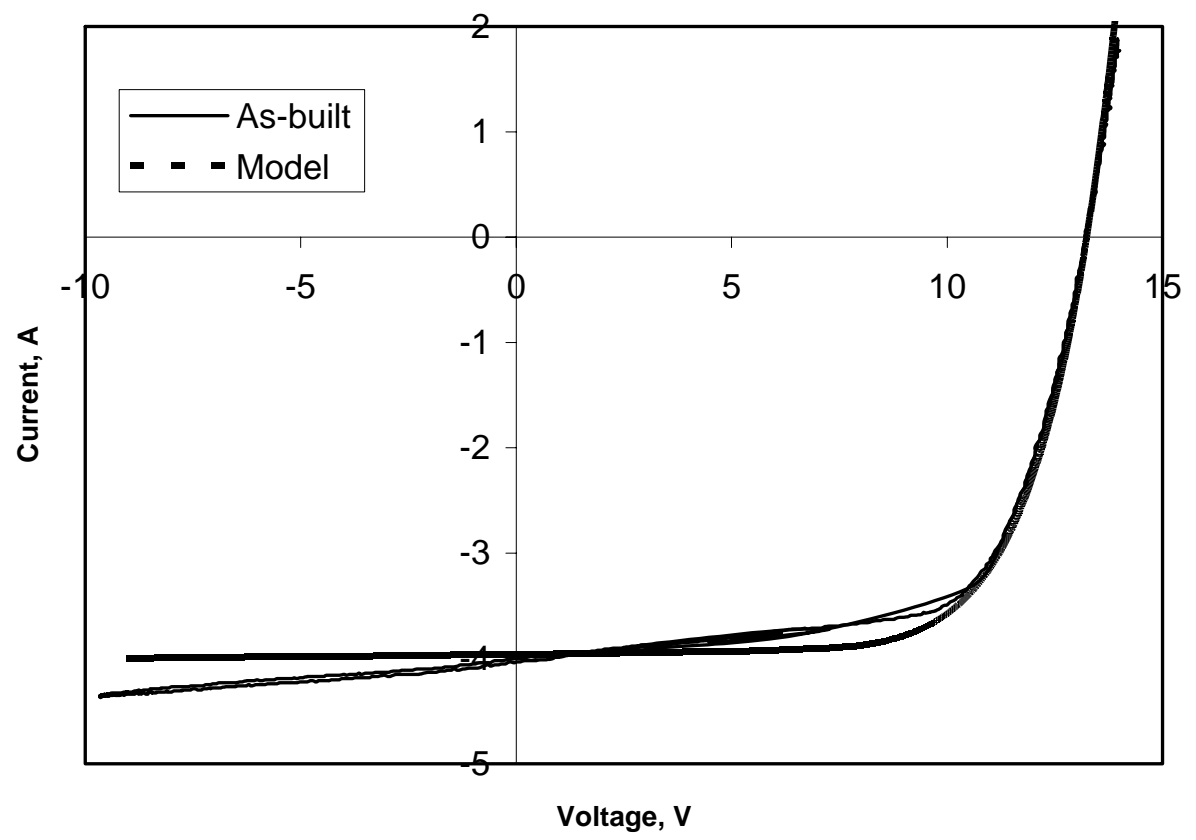

Figure 6. Comparison of simulation and test results for 192-cell array

\section{Conclusions}

Simulation has proven to be a valuable tool in advancing the development of TPV energy conversion systems. Custom-designed simulation software has enabled computational engineering studies that support the fabrication and testing of TPV arrays. The quantification of the sensitivities of network performance to various cell and system 
variables guides the design and assembly of TPV networks. In particular, investigation of the effects of cell variability on network efficiency has contributed to high performing small-scale networks through the selection of cell matching tolerances.

The combination of network modeling and laboratory testing provides an efficient means to evaluate the effects of the many factors which govern network performance. Additional simulation studies must be performed to investigate the sensitivity of network performance to other factors such as non-uniform illumination and cell failure. Quantification of the influence of these operational factors is needed to design TPV arrays that will perform reliably at the required power rating over system design life.

\section{References}

${ }^{1}$ Charache, G.W., P.F. Baldasaro, L.R. Danielson, D.M. DePoy, M.J. Freedman, C.A. Wang, H.K. Choi, D.Z. Garbuzov, R.U. Martinelli, V. Khalfin, S. Saroop, J.M. Borrego, and R.J. Gutman, "InGaAsSb thermophotovoltaic diode: Physics evaluation," Journal of Applied Physics, Vol. 85, 4, 2247-2252 (1999).

${ }^{2}$ Wang, C.A., H.K. Choi, S.L. Ransom, G.W. Charache, L.R. Danielson, and D.M. DePoy, "High-quantum-efficiency 0.5 eV GaInAsSb/GaSb thermophotovoltaic devices," Applied Physics Letters, Vol. 75, 9, 1305-1307 (1999).

${ }^{3}$ Reiche, K., R. Preu, G. Kleiss, and K. Bucher, "Effects of Advantageous Placing of PV Cells and Modules in Generating Units," First World Conference on Photovoltaic Energy Conversion, 1176-1179 (1994).

${ }^{4}$ Pinkerton, R.J., "Solar Array String Characteristics in Strange Places," 35 ${ }^{\text {th }}$ Intersociety Energy Conversion Engineering Conference, 681-691 (2000).

${ }^{5}$ Ortega, P.R. Bermejo, S., Castaner, L.M., "Multichip Module Photovoltaic Miniarrays," IEEE Transactions on Advanced Packaging, Vol 24, 169-174 (2001).

${ }^{6}$ Vaz, C.C., Miranda, L.C.M., Perondi, L.F., "Thermo-Optical Design Analysis Of Space Satellite Solar Arrays,” First World Conference on Photovoltaic Energy Conversion, 2045-2048 (1994).

${ }^{7}$ Gow, J.A. and C.D. Manning, "Development of a photovoltaic array model for use in power-electronics simulation studies," IEE Proceedings on Electrical Power Applications, Vol. 146, 2. March 1999.

${ }^{8}$ Banks, J. and J.S. Carson II, Discrete-Event System Simulation, Prentice-Hall, NJ, 1984.

${ }^{9}$ Sze, S.M., Physics of Semiconductor Devices, John Wiley \& Sons, New York, NY, 1969.

${ }^{10}$ Danielson, L.R., J.R. Parrington, G.W. Charache, G.J. Nichols, and D..M.Depoy, "Measurement Techniques for Single Junction Thermophotovoltaic Cells," Thermophotovoltaic Generation of Electricity: Proceedings Fourth NREL Conference, pp. 317-326 (1999).

${ }^{11}$ Lasnier, F., and Ang, T.G., Photovoltaic Engineering Handbook, Adam Hilger, NY, 1990.

${ }^{12}$ Rauschenbach, H.S., Solar Cell Array Design Handbook, Litton Educational Publishing Inc., NY, 1980.

${ }^{13}$ Ramakrishnan, R. and J. Gehrke, Database Management Systems, $2^{\text {nd }}$ edition, McGraw-Hill, Boston, 2000. 